\title{
COWARDS AND HEROES: \\ GROUP LOYALTY IN THE AMERICAN CIVIL WAR
}

\author{
Dora L. Costa \\ Matthew E. Kahn \\ Working Paper 8627 \\ http://www.nber.org/papers/w8627 \\ NATIONAL BUREAU OF ECONOMIC RESEARCH \\ 1050 Massachusetts Avenue \\ Cambridge, MA 02138 \\ December 2001
}

We have benefited from the comments of Daron Acemoglu, Eli Berman, Stanley Engerman, Edward Glaeser, Daniel Hamermesh, Dean Karlan, Joanna Lahey, Jesse Shapiro, Peter Temin and seminar participants at the 2001 NBER/DAE Summer Institute, the MIT organizational lunch, and Boston University. Dora Costa gratefully acknowledges the support of NIH grants AG12658 and AG10120. The views expressed herein are those of the authors and not necessarily those of the National Bureau of Economic Research.

(C) 2001 by Dora L. Costa and Matthew E. Kahn. All rights reserved. Short sections of text, not to exceed two paragraphs, may be quoted without explicit permission provided that full credit, including $\odot$ notice, is given to the source. 
Cowards and Heroes: Group Loyalty in the American Civil War

Dora L. Costa and Matthew E. Kahn

NBER Working Paper No. 8627

December 2001

JEL No. L39, Z13, N31

\begin{abstract}
What motivated men to risk death in the most horrific war in U.S. history when pay was low and irregular and military punishment strategies were weak? In such a situation creating group loyalty by promoting social capital is of paramount importance and in the Civil War was the cement of both armies. We find that individual and company socio-economic and demographic characteristics, ideology, and morale were important predictors of group loyalty in the Union Army. Company characteristics were more important than ideology or morale. Soldiers in companies that were more homogeneous in ethnicity, occupation, and age were less likely to shirk.
\end{abstract}

Dora L. Costa

MIT

Department of Economics, E52-274C

50 Memorial Drive

Cambridge, MA 02142

and NBER

costa@mit.edu
Matthew E. Kahn

The Fletcher School

Tufts University

Medford, MA 02155

and NBER

matt.kahn@tufts.edu 


\section{Introduction}

The Civil War was the most horrific war in United States history. The total number of deaths in the Civil War equaled the total number killed in almost all other wars combined and more than one out of every five white men participating died, over half of them from disease (Vinovskis 1990). The combatants faced death, the hardships and monotony of camp life, and distance from loved ones, all for low and irregular pay. One soldier wrote, "I have cursed the day I have enlisted for what benifit [sic] will I ever drive from being a Soldier. the common Soldier will not reap the Harvest of Victories but it is some other men that will gain all Praise Honor and Wealth."1 Had he deserted, he would have faced only a 40 percent chance of being caught and a negligible risk of death if arrested (Linderman 1987: 174, 176). A self-interested soldier would have deserted. But, over 90 percent of all Union Army soldiers did not (Linderman 1987) and among Union Army soldiers whose three year enlistment terms were up, half of them re-enlisted (McPherson 1997: 81-82). What motivated these men to soldier on?

This paper investigates the determinants of group loyalty, studying the relative importance of individual and community characteristics, of ideology, and of morale in determining group loyalty among Union Army soldiers. Loyalty can be expressed through cowardice and heroism. The measures of "cowardice" are desertion, arrests, and absences without leave. A measure of "heroism" is promotion from private to officer, though not deserting could also be regarded as heroism. This paper provides the first large-scale quantitative assessment of the correlates of cowardice and heroism based upon soldiers' deeds rather than their words. An unusually rich dataset provides us with detailed demographic and economic characteristics of individuals, of companies, and of the geographical areas from which individuals came. We find that

\footnotetext{
${ }^{1}$ Letter of John S. Voltz to his brother, 2/10/1865, University Libraries of Virginia Tech, http://scholar2.lib.vt.edu/spec/voltz.
} 
individual and company socio-economic and demographic characteristics, ideology, and morale were important predictors of group loyalty in the Union Army.

Our analysis provides insights into firm organizational design. A distinguishing characteristic between the military and the modern firm is the military's inability (except for a mercenary army) to fully compensate individuals for risk and to link pay to performance. ${ }^{2}$ In an organization where workers have discretion and unobserved effort matters, altruism for others and the need for others' respect will mitigate the agency problem. Social capital is therefore an important input into having a productive organization. ${ }^{3}$ O'Reilly, Caldwell, and Barnett (1989) find that in work units where social integration is high, turnover is low. Social capital is also important for the economy as a whole. La Porta et al. (1997) show that worldwide trust is associated with more efficient judiciaries, less corruption, and higher quality government bureaucracies. Knack and Keefer (1997) find that trust predicts economic growth and Guiso et al. (2000) find that it predicts financial development.

Studying the Union Army has many advantages over previous studies of shirking and effort in organizations. One advantage is that the stakes are high. It is costly for a military company if an individual shirks. It is also costly for soldiers to do their duty, thus allowing researchers to obtain a better measure of commitment than firm turnover rates or questions on membership in organizations, the measures commonly used in the social capital and organizational behavior literature. Secondly, it is easier for team members to observe and for researchers to measure shirking in the military than in a modern firm. Thirdly, the way companies were organized provides us with an ideal study design. Our data contain a large number of companies (303),

\footnotetext{
${ }^{2}$ Although the armies of Frederick the Great feared their officers more than their enemies, this has never been true in the United States.

${ }^{3}$ Social capital is defined as aspects of the social structure such as trust, networks, and conventions that encourage collaboration and coordination between friends and strangers (Coleman 1990).
} 
but because each company consists of roughly 100 men, each is small enough so there can be relatively little Tiebout sorting within the company. Because companies were built on a local community basis, companies are heterogeneous whereas they would not be if there were random assignment. However, each company is large enough so that there cannot be perfect Tiebout sorting by groups of friends within companies. Finally, because the job of a soldier was unskilled, largely consisting of learning the movement of linear formations, of obeying orders without hesitation, and of mastering the 9 steps of loading a musket and firing in the direction of an enemy hidden by the smoke of the battlefield (Hess 1997: 18-19, 137), worker skills are perfect substitutes.

\section{Demand and Supply of Organizational Loyalty}

All organizations face potential agency problems. Solutions for mitigating such problems include backloading pay, using promotions as an incentive, and paying bonuses to individuals (Lazear 1979: Gibbons 1998). But, Civil War soldiers who survived expected to be discharged from the war-time military when their enlistment term was up, were lucky if their pay arrived on time, and faced a higher risk of death on the battlefield if promoted because officers led the charges. Military outcomes are produced in a team setting, in which one or more regiments win or lose a battle. In such a case where only team output is observed and individual effort is not, a for profit can use pay for performance incentives to induce the efficient level of individual effort (Holmström 1982). Unlike such an organization, the military substitutes loyalty for high powered incentives. $^{4}$

\footnotetext{
${ }^{4}$ Assuming that output is measuring in terms of battles won, the efficient contract would fine soldiers within a company after they lost a battle (see Theorem 3 in Holmström (1982)), but this would lead to widespread desertion when the expectation of victory was low.
} 
Why are soldiers loyal? Soldiers' survival instincts should lead them to shirk, but altruism for men in their companies, the desire for the respect of men in their companies and in their communities, and belief in the cause will lead them to risk their lives on the battlefield. ${ }^{5}$ If men do not believe in the cause and do not care for the esteem of others (or fear their social sanctions), it is rational to shirk. Concern with personal honor depends in turn upon men's socioeconomic and demographic characteristics and on the characteristics of the organization. Because belief in the cause is less costly when one's side is winning, morale will also determine committment to a military organization. Based upon his reading of soldiers' letters, McPherson (1997) argued that Civil War soldiers were sustained by convictions of duty, honor, patriotism, and ideology, impulses of courage and self-respect, and by fighting units' group cohesion and by peer pressure in their home communities. In reply to questionnaires, WWII enlisted soldiers cited ending the task, solidarity with the group, thoughts of home and loved ones, and a sense of duty and self-respect as the most important factors in movitating them to keep going (Stouffer et al. 1949: 109). In contrast, Bearman (1991) argues that among men from North Carolina, local homogeneity led to high desertion rates.

\section{Empirical Framework}

Our empirical framework can be thought of in terms of the following production functions:

$$
\begin{aligned}
\text { loyalty } & =f(\text { social capital, individual characteristics, }, \text { ideology, morale }) \\
\text { social capital } & =g(\text { individual characteristics }, \text { community characteristics })
\end{aligned}
$$

\footnotetext{
${ }^{5}$ Writing of World War II soldiers, Marshall (1947: 150) observed, "Personal honor is the one thing valued more than life itself by the majority of men." McPherson (1997: 77) finds the phrase "death before dishonor" in Civil War letters and diaries innumerable times.
} 
Table 1: Determinants of Group Loyalty

\begin{tabular}{llll}
\hline \hline \multicolumn{1}{c}{ Individual } & \multicolumn{1}{c}{ Community } & \multicolumn{1}{c}{ Ideology } & \multicolumn{1}{c}{ Morale } \\
\hline Social status & Birth place fragmentation & Year mustered in & Percent in company dying \\
Occupation & Occupational fragmentation & Volunteer status & Fraction Union victories \\
Family wealth & Age diversity & From pro-Lincoln county & \\
Literacy & Size of city of enlistment & & \\
Nativity & Brother in company & & \\
Native-born & Percent of own nativity & & \\
German & Percent of own occupation & & \\
Irish & & & \\
English & & & \\
Other & & & \\
Age & & & \\
Marital status & & & \\
\hline \hline
\end{tabular}

Since we do not explicitly measure social capital, we substitute Equation 2 into Equation 1 and model loyalty as a function of individual characteristics, community characteristics, ideology, and morale. Table 1 lists the sets of variables determining group loyalty. We will examine the relative impact of these four types of variables on group loyalty, measuring loyalty using days until desertion, AWOL, arrests, and promotion to officer and examining days until one of these events using a competing risks framework.

Socio-economic and demographic characteristics of soldiers affect group loyalty because they shape soldiers' ideology and affect their productivity within an organization. As noted in Table 1, these characteristics include birth place, marital status, age, and social status (as proxied by occupation, family wealth, and literacy). Birthplace and social status influence ideas of patriotism, honor, and duty. Older soldiers may be more disciplined. Married men may be either more or less motivated to fight by the thought of loved ones. Studies of American soldiers in World War II found combat performance to correlate positively with social class and education, age, and being married (Stouffer et al. 1949: 36-37). In the case of Civil War soldiers, 
the sense of duty and honor and the potential for public shame was probably greater among the more socially prominent. Germans who fled the revolutions of 1848 may have been more likely than Irish or British immigrants who migrated for economic reasons to view the United States as the best hope for the survival of a form of republican government. Protestant Germans were more likely to be Republican than the Irish because a large proportion of Republican voters were anti-Catholic Know-Nothings (Fogel 1989: 384). Financial hardship at home led some married men to desert, but this was probably truer of Confederate soldiers whose families faced food shortages (McPherson 1997: 138). The importance of individual characteristics to individuals' commitment to organizations is observed in civilian life as well. The modern military and the human resource departments of corporations select individuals on the basis of their characteristics. Ichino and Maggi (2000) find that region of birth, age, education, tenure, and promotion rate are important predictors of worker absences and misconduct. Group loyalty requires interactions with fellow workers or community members, but committment to interacting with others varies by demographic group (Glaeser, Laibson, and Sacerdote 2000).

Community characteristics influence group participation. Previous studies examined the effect of community characteristics on public expenditures (Luttmer 2001; Poterba 1997; Alesina, Baquir, and Easterly 1999; Goldin and Katz 1999) and on time allocation and organizational membership (Alesina and La Ferrara 2000; Costa and Kahn 2001). In contrast, we examine willingness to risk death. Our primary measure of a soldier's community is the company he was in. We examine the effect of such company characteristics as birth place fragmentation, economic fragmentation (proxied by occupational fragmentation), age diversity, and the percent of the company of own ethnicity and occupation on group loyalty. We also investigate the impact of other definitions of community, including whether the soldier had a brother, father, or son in the same company and population size of city of enlistment. Some studies (e.g. Watson 1978: 117) have argued that the most effective military squads are those that are psychologically 
homogeneous. Within heterogeneous units team production may therefore be harder because there is less social integration and less informal communication and because communication is less frequent. Team production may also be harder because social sanctions are less effective. The notion that intense loyalty, to the point of self-sacrifice, to a small band of comrades is soldiers' primary motivation for fighting became widespread among sociologists, psychologists, and military historians after World War II (McPherson 1997: 86). Because soldiers live with the same men for so long, endangering the group leads to personal guilt and ostracism within the group. Some have argued that this group loyalty was also evident among Civil War soldiers, where feelings of loyalty were compounded by community pressure since fellow soldiers from the same hometown could and did report on others' behavior (McPherson 1997: 77-89). Empirical evidence examining individual interactions has found that the more similar are pairs of individuals, the higher is trust (Glaeser, Laibson, Scheinkman, and Soutter 2000). Studies of firms have found that heterogeneity in age, education, tenure, race, and sex is positively related to turnover, but which of these heterogeneity measures is more important depends upon the organization studied. ${ }^{6}$ We cannot tell apriori whether such measures of community heterogeneity as fragmentation indexes are better predictors of group loyalty than the percent of the company of own ethnicity or occupation.

Although we assume that social capital is a productive input into group loyalty, we realize that there could be a "dark side" of social capital such that greater homogeneity contributes to shirking and to favoritism. There is evidence that by sustaining local area loyalties, company heterogeneity bred higher desertion rates (Bearman 1991).

Ideological fervor bolsters loyalty and will therefore mitigate the agency problem. Questionnaires administered to American volunteers in the Spanish Civil War found that ideology

\footnotetext{
${ }^{6}$ See Pfeffer (1997: 83-85) for a review. Sørenson (2000) argues that it is not just current but also previously experienced demographic heterogeneity within a firm that matters.
} 
was the single most important factor helping men to overcome fear in battle (Dollard 1943: 55), whereas among World War II soldiers it played only a small role (Stouffer et al. 1949: 109). During the American Civil War, not just own ideology but also ideology of the soldiers' hometown was an important factor. Soldiers' morale depended not just upon good news from the front, but also upon their families' and communities' support. We measure ideology using year of enlistment, volunteer status, and percent of the county voting for Lincoln. Men who enlisted after 1962 were commonly described as being without patriotism, honor, or interest in the cause (McPherson 1997: 9). The constituencies voting for Lincoln were diverse, consisting of anti-Catholics, farmers, and land reformers, among others, opposed to slavery on both economic and moral grounds (Fogel 1989: 369-387). Soldiers' committment to the cause may have grown the longer they served in the army. When Lincoln ran for re-election he received 78 percent of the soldier vote compared to 53 percent of the civilian vote, despite some 40 to 45 percent of soldiers having come from Democratic families in 1860 (McPherson 1997: 176). We can test whether soldiers' committment increased by examining whether cowardice hazards decrease with time and whether heroism hazards increase with time.

Another important determinant of group loyalty is the morale of the troops. Morale will depend upon support from the home front, leadership, and also upon the own unit's and the entire Army's success on the battlefield. The ideologically committed men who served in the Spanish Civil War cited defeats, retreats, and heavy casualties, ignorance of objectives and lack of reliable news, and poor food, clothing, and shelter as the most common conditions in which demoralizing rumors were likely to spring up (Dollard 1943: 53). Morale is a dynamic variable. In 1865 desertion reached epidemic levels in the Confederate Army when it was clear that the Confederacy could not win. In the Union Army, desertion reached a high point after the removal of McClellan in November 1862, the defeats at Fredericksburg and at Chickasaw Bluffs in December 1862, the rise of the peace Democrats at home, and the controversy over 
emancipation. Morale revived with victories at Gettysburg and at Vicksburg in July of 1863, though continued gyrations were in store for the troops (McPherson 1997: 155-162).

\section{The Union Army}

On the eve of the Civil War, the regular army consisted of only 15,000 enlisted men. ${ }^{7}$ By the end of the war over 2 million men had served in the Union Army, with four out of five men born in the prime birth cohorts of 1837-1845 serving. From April 1861 to July 1862 the army depended solely upon volunteers enlisting for low pay. In July 1862, the Militia Act assigned quotas to each state to fill and these in turn assigned quotas to towns. When patriotic appeals failed, states and towns began offering men bounties to induce them to enlist so that they could fill their quotas. In March 1863 the Enrollment Act created a conscription system administered by the federal government. Quotas were assigned to each congressional district and then broken down into subdistricts within each district. When towns failed to meet their quotas, every able-bodied male citizen between the ages of 20 and 45 became eligible for the draft, though married men were less likely to be called. Draftees could hire a substitute to take their place or they could pay a commutation fee of $\$ 300$ (equal to the yearly wage of an average worker) to be exempt from that particular draft, though not from another. Draftees and substitutes were relatively rare, constituting no more than 10 percent of all soldiers. Paying a commutation fee was also rare. Only 87,000 men became exempt in this way.

States and individuals played a large role in the formation of regiments of volunteers, the basic units of the armies. The volunteer infantry regiments consisted of 10 companies, each

\footnotetext{
${ }^{7}$ See Hattaway (1997), Gould (1869), and U.S. Provost Marshall General (1866) for a detailed discussion of the organization of the Civil War Armies and Linderman (1987), Kemp (1990), Mitchell (1990), and McPherson (1997) for discussions of soldiers and their communities.
} 
containing roughtly 100 men, commanded by a captain and two lieutenants, often volunteer officers drawn from state militias, men of political significance, or assorted prominent men in the community. Professional officers were not necessarily more skilled in military matters because the West Point curriculum emphasized engineering rather than military tactics. Regiments were typically formed from men who came from the same area. Each company would generally contain bands of men who had known each other in civilian life. ${ }^{8}$ Mitchell (1990) argues that this way of recruiting was not accidental. The voluntary organization of small communities into a national army, the amalgation of civic pride and national patriotism, was how the volunteers imagined the Union should function. Because of the strong loyalties men felt toward their companies, a company was not replenished with new men when disease, military casualties, and expirations of enlistment terms whittled down a company's numbers. If a company's numbers were sufficiently reduced, the company disappeared and the men who continued to fight would transfer to another company.

Soldiers reported home on the cowardice, courage, and moral behavior of their comrades, thus bringing home peer pressure to bear on men's behavior. Companies maintained constant contact with their home communities through local newspapers and letters that never had to pass a censor's desk, arriving with the same speed as mail today unless soldiers were in the deep South. Companies could also increase social integration among like-minded individuals. Soldiers formed debate societies and organizations of Christian associations.

The Union Army was not held together by discipline. Citizens visited their friends in camp at all hours of the day. Except for some camp drills, most men and company commanders learned on the job. When officers were men soldiers had known all their lives, the men had

\footnotetext{
${ }^{8}$ Finding a company that was a good match could be a matter of luck. One soldier wrote home, "We have a remarkable civil and Religious company ... $\mathrm{i}$ think it is a providencial circumstance that I enlisted in this company for I hear that there is desperate wickedness in very regiments i came so near enlisting in." (Letter of David Close, November 4, 1862, 126th Ohio Volunteer Infantry, Company D, http://www.iwaynet.edu/lsci/
} 
trouble thinking of officers as their superiors and were slow to or refused to follow orders. The officers who commanded respect were those concerned for the welfare of their men and those who demonstrated personal courage and a willingness to do themselves what they asked of their men. Those who commanded contempt resigned their commissions, driven out by the ill-will of their men.

The Army's coercive powers were limited. As the war progressed, the Army designated units of provost guards to drive stragglers (men who milled at the rear) into line. However, because they were reluctant to shoot soldiers wearing the same uniform, they were not always effective. Similarly, executions for such serious penalties as desertion were relatively rare. Out of roughly 200,000 deserters, 80,000 were caught and returned to the army and 147 were executed for desertion (Linderman 1987: 174, 176). Executions were loathsome both to soldiers and to civilians. Instead the penalties for desertion, and also AWOL, generally ranged from fines and loss of pay to imprisonment (including with hard labor) to performance of the more onerous duties in the company to the social sanctions of men's home communities.

\section{Data}

Our data consist of 31,854 white, enlisted men in 303 Union Army infantry companies. ${ }^{9}$ The sample represents roughly 1.3 percent of all whites mustered into the Union Army and 8 percent of all regiments that comprised the Union Army. The data are based upon a random sample of 331 companies drawn at the company level. ${ }^{10}$ Ninety-one percent of the sample consists of volunteers,

\footnotetext{
${ }^{9}$ The data were collected by Robert Fogel and are available from http://www.cpe.uchicago.edu.

${ }^{10}$ Our sample is limited to 303 companies because complete data have not yet been collected on all 331 companies. Among the original 331 companies, New England is under-represented and the Midwest over-represented relative to the army as a whole. The companies that have not yet been collected are from Indiana and Wisconsin, states that were unusually committed to the Union cause.
} 
with the remainder evenly divided between draftees and substitutes. In terms of real estate and personal property wealth, the sample is representative of the 1860 age-adjusted population (Fogel 2001). The primary data source consists of men's military service records. These records provide such basic information as year of muster, age, birthplace, and height in inches, and also information on what happened to the soldier during his military service. Desertions, arrests, and AWOLs were handled by military courts convened in the field. Men were linked to the manuscript schedules of the 1860 census which provides information on the value of personal property for all individuals in the household and on illiteracy and allows us to infer marital status. (Linkage details are provided in the Appendix.) We merged data on population in city of enlistment and voting in the 1860 presidential election (see the Appendix for sources). We include region fixed effects for New England, Middle Atlantic, East North Central, West North Central, Border, and West.

Table 2 illustrates the wide variation in shirking and mortality rates by state. Shirking was high in the border states of Kentucky and Maryland. Of particular note are the high promotion rates in Wisconsin and Iowa.

We constructed variables describing recruits' individual characteristics, the characteristics of their communities, their ideological fervor, and their morale (see the Appendix for details). Our individual variables consist of occupational class, country of birth, age, height in inches (a measure of productivity), the soldier's marital status in 1860, total personal property wealth in the soldier's 1860 household, and whether the soldier was illiterate. Our community variables consist of company birthplace fragmentation, company occupational fragmentation, the coefficient of variation for age for the company, and the size of the town the recruit enlisted in. Soldiers from large cities who shirked were more likely to be able return to their home towns without facing social sanctions from the whole town. We also created community variables for the percent of the company of a given ethnicity or occupation and for whether the recruit had a brother in the 
Table 2: Percent Serving by State and Percent Deserted, Arrested, AWOL, Promoted to Officer, and Died in War by State

\begin{tabular}{lllllll}
\hline \hline & \% Serving & \% Deserted & \% Arrested & \% AWOL & \% Promoted & \% Died \\
\hline Connecticut & 1.65 & 3.13 & 1.86 & 3.05 & 0.00 & 1.84 \\
Maine & 1.31 & 0.67 & 2.32 & 0.86 & 0.61 & 1.80 \\
Massachusetts & 1.65 & 0.94 & 1.70 & 1.05 & 0.61 & 1.90 \\
New Hampshire & 1.85 & 3.07 & 2.17 & 3.62 & 0.30 & 2.97 \\
Vermont & 0.96 & 0.00 & 0.00 & 0.00 & 0.00 & 0.41 \\
Delaware & 1.39 & 1.70 & 1.86 & 0.57 & 0.30 & 0.86 \\
New Jersey & 2.77 & 6.66 & 5.11 & 1.33 & 0.30 & 1.52 \\
New York & 19.81 & 26.09 & 31.11 & 30.03 & 12.12 & 20.53 \\
Pennsylvania & 9.41 & 9.49 & 3.87 & 4.86 & 1.52 & 7.78 \\
Illinois & 12.18 & 10.82 & 6.35 & 8.10 & 6.06 & 13.47 \\
Indiana & 4.22 & 3.10 & 2.17 & 5.15 & 9.39 & 4.43 \\
Michigan & 4.50 & 3.53 & 3.41 & 3.05 & 2.42 & 5.07 \\
Ohio & 17.48 & 13.77 & 7.89 & 15.92 & 13.64 & 18.31 \\
Wisconsin & 4.36 & 1.34 & 2.79 & 1.72 & 17.88 & 3.08 \\
Iowa & 4.32 & 1.00 & 4.18 & 3.05 & 20.30 & 6.46 \\
Kansas & 0.82 & 0.24 & 0.62 & 0.19 & 3.03 & 0.19 \\
Minnesota & 0.93 & 0.30 & 0.46 & 0.48 & 0.91 & 0.26 \\
Missouri & 3.20 & 2.77 & 3.10 & 2.38 & 6.67 & 3.93 \\
Kentucky & 2.84 & 4.96 & 1.55 & 9.06 & 1.21 & 3.21 \\
Maryland & 0.92 & 1.89 & 1.39 & 2.10 & 0.00 & 0.83 \\
Washington, DC & 0.37 & 0.49 & 1.70 & 1.24 & 0.00 & 0.02 \\
West Virginia & 1.05 & 0.27 & 0.62 & 1.24 & 0.00 & 0.49 \\
New Mexico & 0.30 & 0.70 & 2.01 & 0.10 & 0.00 & 0.02 \\
California & 1.73 & 3.07 & 11.76 & 0.86 & 2.73 & 0.62 \\
\hline \hline
\end{tabular}

31,850 observations. Arrests and AWOLs are those preceding desertion only. 
company. Our ideology variables consist of the year the soldier was mustered in, his volunteer status, and the percent of all votes in the soldier's county of enlistment for Lincoln (a measure of the soldier's own and the community's ideology). Our measures of morale are both company specific and for the Army as a whole and consist of the fraction of the company who died for each half year that the soldier was in the company and the fraction of Union victories to all major battles for each half year that the soldier was in the service. Both of these variables are time-varying covariates. Note that the fraction of Union victories to major battles does not vary across companies and only varies across individuals who were mustered in at different dates. We do not treat the other company variables as time-varying covariates because there was very little change in company characteristics from the start to the end of their service. Note that we cannot include company leader characteristics as a variable because we know leader characteristics only for internal promotions.

Table 3 lists all variables used in the regression tables and shows that the sample means for those who deserted, were arrested, were AWOL, and were promoted to officer differ substantially from those for the entire sample. To simplify the tables we do not include as covariates the fraction of the company that is of soldier's own ethnicity or occupation or whether the soldier had a brother in the company; instead, we describe the results in the text. Among shirkers, the individual level variables that differ are occupation, birth place, and household wealth. The community level variables that differ are company birth place fragmentation, occupational fragmentation, and coefficient of variation for age, and population size in city of enlistment. The ideology variables that differ are year of muster, volunteer status, and the percent of votes cast for Lincoln. Shirking also occurs when the company death rate is high and when Army-wide morale is low. Those promoted to officer were native-born professionals and proprietors who volunteered in 1861 and who were from high mortality companies. 
Table 3: Variable Means for All Men, for Deserted, for Arrested, for AWOL, and for Promoted to Officer

\begin{tabular}{|c|c|c|c|c|c|}
\hline & All & Deserted & Arrested & AWOL & Promoted \\
\hline Days from muster until & & 190.644 & 385.175 & 356.181 & 301.776 \\
\hline \multicolumn{6}{|l|}{ Dummy $=1$ if occupation } \\
\hline Farmer & 0.511 & $0.326^{\ddagger}$ & $0.387^{\ddagger}$ & 0.493 & $0.576^{\dagger}$ \\
\hline Artisan & 0.200 & $0.243^{\ddagger}$ & 0.195 & 0.191 & 0.173 \\
\hline Professional/proprietor & 0.075 & $0.086^{\ddagger}$ & 0.085 & 0.076 & $0.112^{\ddagger}$ \\
\hline Laborer & 0.207 & $0.338^{\ddagger}$ & $0.330^{\ddagger}$ & $0.236^{\dagger}$ & $0.103^{\ddagger}$ \\
\hline Unknown & 0.007 & 0.007 & 0.003 & 0.004 & $0.036^{\ddagger}$ \\
\hline \multicolumn{6}{|l|}{ Dummy $=1$ if born in } \\
\hline US & 0.755 & $0.599^{\ddagger}$ & $0.591^{\ddagger}$ & $0.708^{\ddagger}$ & $0.842^{\ddagger}$ \\
\hline Germany & 0.071 & $0.082^{\ddagger}$ & 0.065 & 0.066 & 0.052 \\
\hline Ireland & 0.084 & $0.165^{\ddagger}$ & $0.203^{\ddagger}$ & $0.125^{\ddagger}$ & $0.036^{\ddagger}$ \\
\hline Great Britain & 0.038 & $0.071^{\ddagger}$ & $0.074^{\ddagger}$ & $0.051^{\dagger}$ & 0.033 \\
\hline Other & 0.052 & $0.082^{\ddagger}$ & $0.067^{*}$ & 0.050 & 0.036 \\
\hline Age at enlistment & 25.774 & $25.530^{\dagger}$ & 25.735 & 25.844 & 25.530 \\
\hline Height in inches at enlistment & 67.623 & $67.200^{\ddagger}$ & $67.348^{+}$ & 67.595 & $68.581^{\ddagger}$ \\
\hline Dummy $=1$ if married & 0.133 & $0.084^{\ddagger}$ & $0.080^{\ddagger}$ & 0.135 & 0.136 \\
\hline Log(total household personal property), 1860 & 1.639 & $0.743^{\ddagger}$ & $1.014^{\ddagger}$ & $1.364^{\ddagger}$ & $1.988^{\dagger}$ \\
\hline Dummy $=1$ if illiterate & 0.017 & 0.018 & 0.015 & $0.031^{\ddagger}$ & $0.003^{\dagger}$ \\
\hline \multicolumn{6}{|l|}{ Company characteristics } \\
\hline Birth place fragmentation & 0.564 & $0.614^{\ddagger}$ & $0.648^{\ddagger}$ & $0.591^{\ddagger}$ & $0.634^{\ddagger}$ \\
\hline Occupational fragmentation & 0.549 & $0.620^{\ddagger}$ & $0.613^{\ddagger}$ & $0.566^{\ddagger}$ & $0.459^{\ddagger}$ \\
\hline Coefficient of variation for age $\times 100$ & 28.373 & 28.394 & $27.492^{\ddagger}$ & $28.596^{\dagger}$ & $27.822^{\ddagger}$ \\
\hline $\log ($ population) city enlistment & 8.599 & $9.377^{\ddagger}$ & $9.067^{\ddagger}$ & $8.870^{\ddagger}$ & $8.124^{\ddagger}$ \\
\hline \multicolumn{6}{|l|}{ Dummy $=1$ if mustered in } \\
\hline 1861 & 0.210 & $0.190^{\ddagger}$ & $0.302^{\ddagger}$ & $0.354^{\ddagger}$ & $0.291^{\ddagger}$ \\
\hline 1862 & 0.351 & 0.347 & 0.339 & 0.331 & $0.400^{*}$ \\
\hline 1863 & 0.064 & $0.126^{\ddagger}$ & $0.096^{\ddagger}$ & 0.057 & $0.039^{*}$ \\
\hline 1864 & 0.254 & $0.197^{\ddagger}$ & $0.215^{\dagger}$ & $0.204^{\ddagger}$ & $0.100^{\ddagger}$ \\
\hline 1865 & 0.120 & $0.140^{\ddagger}$ & $0.048^{\ddagger}$ & $0.054^{\ddagger}$ & $0.170^{\ddagger}$ \\
\hline Dummy $=1$ if volunteer & 0.907 & $0.842^{\ddagger}$ & 0.895 & 0.893 & $0.997^{\ddagger}$ \\
\hline \multicolumn{6}{|l|}{ Percent in county of enlistment voting for } \\
\hline Lincoln & 35.525 & 35.465 & $31.033^{\ddagger}$ & $30.281^{\ddagger}$ & $32.697^{\dagger}$ \\
\hline Vote for other & $34.777^{\ddagger}$ & 40.455 & 35.686 & $37.212^{\ddagger}$ & $30.636^{\ddagger}$ \\
\hline Unknown & 29.698 & $24.080^{\ddagger}$ & $33.282^{\dagger}$ & $32.507^{\dagger}$ & $36.667^{\ddagger}$ \\
\hline Percent in company dying & 13.712 & $12.880^{\ddagger}$ & $11.595^{\ddagger}$ & 13.982 & $14.601^{*}$ \\
\hline Fraction Union victories in 6 months of event & 0.450 & $0.273^{\ddagger}$ & $0.410^{\ddagger}$ & $0.393^{\ddagger}$ & $0.373^{\ddagger}$ \\
\hline Number of observations & 31,850 & 3289 & 646 & 1049 & 330 \\
\hline
\end{tabular}

The symbols $*, \uparrow$, and $\ddagger$ indicate that the mean is significantly different from the mean for those not in the category at the 10,5, and 1 percent level, respectively. Arrests and AWOLs are those preceding desertion only. The logarithm of personal property wealth is set equal to zero for those for whom this information is missing. The standard deviations of $\log$ (total household personal property), birth place fragmentation, occupational fragmentation, the coefficient of variation for age, the percent in the company dying, and $\log$ (population) are 2.699, 0.204, 0.181, 3.193, 8.667, and 1.874 , respectively. 


\section{Econometric Framework}

Our measures of cowardice and heroism are desertion, arrest, AWOL, and promotion to officer. Desertion is the best measure of shirking. Arrests and promotions depend upon officer decisions. Desertion is a more serious offense than AWOL and, because 10 percent of the sample deserted, it also is the measure with the largest number of outcomes. Absences without leave were generally failing to return from furlough on time and straggling from the company. Arrests that were not for desertions or AWOL were for drunkenness, assault, robbery, insubordination, and sleeping while on picket duty.

Our empirical strategy uses a time-varying competing risk hazard model to estimate days from entry into the company (muster-in) until desertion, arrest, AWOL, or promotion to officer. We use a competing risk framework because some men may have died, been discharged, changed company, become prisoners of war, or be missing in action before they could desert. Similarly, some men may have died, been discharged, changed company, become prisoners of war, be missing in action, or have deserted before arrest, AWOL, or promotion to officer (see Figure 1). Hazard models provide a framework to estimate the micro and macro determinants of cowardice and heroism. Our estimated hazard, $\lambda(t)$, is

$$
\lambda(t)=\exp \left(x_{I}^{\prime} \beta_{I}+x_{C}^{\prime} \beta_{C}+x_{D}^{\prime} \beta_{D}+x_{M}^{\prime} \beta_{M}\right) \lambda_{0}(t)
$$

where I indexes the individual variables, $\mathrm{C}$ indexes the community variables, $\mathrm{D}$ indexes the ideology variables, $\mathbf{M}$ indexes the morale variables and $\lambda_{O}(t)$ is the baseline hazard which we assume to be Weibull. The survival function thus takes the form, $\exp \left(\left(-\lambda_{j} t_{j}\right)^{p}\right)$ for subject $\mathrm{j}$, where $\mathrm{p}$ is the duration dependence parameter and can be interpreted as representing whether men who were in the war longer became more or less committed soldiers. We present results both with and without the morale variable. The hazard ratios that we report indicate whether a one 
Figure 1: Schematic of Events Studied

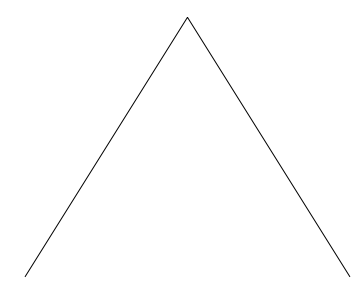

Died, MIA, Lived

POW,

Discharged,

Changed

company

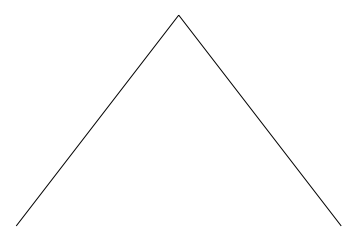

\section{Deserted Stayed}

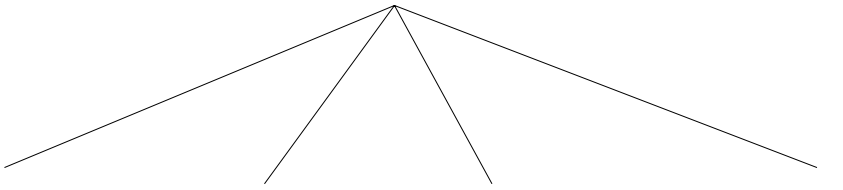

Arrested

AWOL Promoted to

Other

Officer 
unit change in an independent variable gives an increase/decrease in the odds of an event. Thus a hazard ratio of 1.3 on our Irish-born dummy variable indicates that the Irish were 1.3 times as likely as the native-born to desert. We account for unobserved company-level correlation by using variance correction models (Lee, Wei, and Amato 1992; Cai, Wei, and Wilcox 2000). Clustering on companies provides us with a lower bound on the standard error of company characteristics. ${ }^{11}$

\section{Results}

Our results show that individual characteristics, community characteristics, ideology, and morale were all important predictors of cowardice and heroism. However, the relative importance of these variables depends upon whether we examine desertions, arrests, AWOLs, or promotions to officer (see Tables 4, 5, 6, and 7).

Consider first individual characteristics. In the case of desertion, arguably our best measure of shirking, men who were farmers, who were older, who came from a household with high property wealth in 1860 , and who were literate were less likely to desert. ${ }^{12}$ Relative to the native-born the Irish and British were more likely to desert. They were also twice as likely to be arrested as the native-born. Married men were significantly more likely to desert, but the interaction term on married and personal property wealth was insignificant, suggesting that financial hardship at home did not necessarily lead to disproportionate desertions among married

\footnotetext{
${ }^{11}$ We estimate contextual interactions, wherein a soldier's behavior varies with such exogenous characteristics of the group as ethnic diversity. We also account for correlated effects at the company level arising from such factors as men's trust and opinion of the captain and lieutenants commanding the company and variation in punishments for desertion or AWOL by company. We do not attempt to identify endogenous interactions, wherein the soldier's behavior varies with the behavior of the group because while we observe individuals if they move out of a company, very few did and for those who did we cannot observe the characteristics of the company they move into. See Manski (2000) and (1993) for a discussion of endogenous interactions, contextual effects, and correlated effects.

${ }^{12}$ If all men in the sample had come from the wealthiest household (one in which the logarithm of personal property wealth was 10.8), the average predicted probability of desertion would have been 0.056 instead of 0.094 .
} 
Table 4: Desertion Competing Risk Hazard Model

\begin{tabular}{|c|c|c|c|c|c|c|}
\hline & $\begin{array}{l}\text { Hazard } \\
\text { Ratio } \\
\end{array}$ & $\begin{array}{l}\text { Std } \\
\text { Err }\end{array}$ & $\begin{array}{c}\text { Hazard } \\
\text { Ratio } \\
\end{array}$ & $\begin{array}{l}\text { Std } \\
\text { Err }\end{array}$ & $\begin{array}{c}\text { Hazard } \\
\text { Ratio } \\
\end{array}$ & $\begin{array}{l}\text { Std } \\
\text { Err }\end{array}$ \\
\hline \multicolumn{7}{|l|}{ Dummy $=1$ if occupation } \\
\hline \multicolumn{7}{|l|}{ Farmer } \\
\hline Artisan & $1.443^{\ddagger}$ & 0.075 & $1.443^{\ddagger}$ & 0.094 & $1.435^{\ddagger}$ & 0.093 \\
\hline Professional/proprietor & $1.369^{\ddagger}$ & 0.098 & $1.369^{\ddagger}$ & 0.106 & $1.359^{\ddagger}$ & 0.105 \\
\hline Laborer & $1.578^{\ddagger}$ & 0.079 & $1.578^{\ddagger}$ & 0.121 & $1.572^{\ddagger}$ & 0.121 \\
\hline \multicolumn{7}{|l|}{ Dummy $=1$ if born in } \\
\hline \multicolumn{7}{|l|}{ US } \\
\hline Germany & $0.888^{*}$ & 0.061 & 0.888 & 0.146 & 0.884 & 0.146 \\
\hline Ireland & $1.312^{\ddagger}$ & 0.073 & $1.312^{\ddagger}$ & 0.103 & $1.310^{\ddagger}$ & 0.103 \\
\hline Great Britain & $1.395^{\ddagger}$ & 0.102 & $1.395^{\ddagger}$ & 0.148 & $1.396^{\ddagger}$ & 0.148 \\
\hline Other & $1.249^{\ddagger}$ & 0.085 & $1.249^{\dagger}$ & 0.120 & $1.245^{\dagger}$ & 0.120 \\
\hline Age at enlistment & $0.985^{\ddagger}$ & 0.003 & $0.985^{\ddagger}$ & 0.003 & $0.985^{\ddagger}$ & 0.003 \\
\hline Height in inches at enlistment & 1.002 & 0.007 & 1.002 & 0.008 & 1.002 & 0.008 \\
\hline Dummy $=1$ if married & $1.385^{\ddagger}$ & 0.116 & $1.385^{\ddagger}$ & 0.128 & $1.382^{\ddagger}$ & 0.128 \\
\hline Log(total household personal property), 1860 & $0.951^{\ddagger}$ & 0.013 & $0.951^{\ddagger}$ & 0.017 & $0.950^{\ddagger}$ & 0.017 \\
\hline Dummy $=1$ if illiterate & $1.594^{\ddagger}$ & 0.222 & $1.594^{\ddagger}$ & 0.242 & $1.601^{\ddagger}$ & 0.243 \\
\hline \multicolumn{7}{|l|}{ Company-level measures } \\
\hline Birth place fragmentation & $1.395^{\ddagger}$ & 0.163 & 1.395 & 0.492 & 1.405 & 0.496 \\
\hline Occupational fragmentation & $3.414^{\ddagger}$ & 0.557 & $3.414^{\dagger}$ & 1.681 & $3.428^{\dagger}$ & 1.682 \\
\hline Coefficient of variation for age $\times 100$ & $1.031^{\ddagger}$ & 0.007 & $1.031^{*}$ & 0.017 & $1.032^{*}$ & 0.017 \\
\hline $\log$ (population) city enlistment & $1.059^{\ddagger}$ & 0.011 & $1.059^{\dagger}$ & 0.028 & $1.058^{\dagger}$ & 0.028 \\
\hline \multicolumn{7}{|l|}{ Dummy $=1$ if mustered in } \\
\hline \multicolumn{7}{|l|}{1861} \\
\hline 1862 & $1.597^{\ddagger}$ & 0.082 & $1.597^{\ddagger}$ & 0.193 & $1.632^{\ddagger}$ & 0.200 \\
\hline 1863 & $2.254^{\ddagger}$ & 0.153 & $2.254^{\ddagger}$ & 0.412 & $2.338^{\ddagger}$ & 0.437 \\
\hline 1864 & $1.429^{\ddagger}$ & 0.087 & $1.429^{\ddagger}$ & 0.189 & $1.472^{\ddagger}$ & 0.196 \\
\hline 1865 & $2.694^{\ddagger}$ & 0.182 & $2.694^{\ddagger}$ & 0.446 & $2.628^{\ddagger}$ & 0.437 \\
\hline Dummy $=1$ if volunteer & $0.749^{\ddagger}$ & 0.042 & $0.749^{\dagger}$ & 0.100 & $0.749^{\dagger}$ & 0.100 \\
\hline \multicolumn{7}{|l|}{ Percent in county of enlistment voting for } \\
\hline Lincoln & $0.995^{\ddagger}$ & 0.001 & $0.995^{\dagger}$ & 0.003 & $0.995^{*}$ & 0.003 \\
\hline Percent in company dying (time-varying) & $1.037^{\ddagger}$ & 0.005 & $1.037^{\ddagger}$ & 0.010 & $1.036^{\ddagger}$ & 0.011 \\
\hline Fraction Union victories (time-varying) & & & & & $0.610^{\ddagger}$ & 0.075 \\
\hline Duration dependence parameter & 0.643 & 0.010 & 0.643 & 0.026 & 0.682 & 0.027 \\
\hline Clustered on Company & $\mathrm{N}$ & & Y & & Y & \\
\hline \multicolumn{7}{|l|}{$\chi^{33}, \chi^{33}, \chi^{34}$ for } \\
\hline Significance of all coefficients & 2167.81 & & 791.23 & & 784.32 & \\
\hline
\end{tabular}

Days until desertion are measured from first mustering in. The symbols $*, \uparrow$, and $\ddagger$ indicate that the coefficient is significantly different from 1 at the 10,5, and 1 percent level, respectively. Significance of all coefficients is for equality of all coefficients to 1. Men who died, became POWs, were discharged, were missing in action, or changed companies before first desertion are treated as censored. Covariates include dummy variables indicating missing information for occupation, the 1860 census, literacy, and county voting. Included region fixed effects are for Middle Atlantic, East North Central, West North Central, Border, and West (New England is the omitted category). 
Table 5: Arrest Competing Risk Hazard Model

\begin{tabular}{|c|c|c|c|c|c|c|}
\hline & $\begin{array}{c}\text { Hazard } \\
\text { Ratio }\end{array}$ & $\begin{array}{l}\text { Std } \\
\text { Err }\end{array}$ & $\begin{array}{c}\text { Hazard } \\
\text { Ratio }\end{array}$ & $\begin{array}{l}\text { Std } \\
\text { Err }\end{array}$ & $\begin{array}{c}\text { Hazard } \\
\text { Ratio }\end{array}$ & $\begin{array}{l}\text { Std } \\
\text { Err }\end{array}$ \\
\hline \multicolumn{7}{|l|}{ Dummy $=1$ if occupation } \\
\hline \multicolumn{7}{|l|}{ Farmer } \\
\hline Artisan & 0.931 & 0.111 & 0.931 & 0.115 & 0.925 & 0.115 \\
\hline Professional/proprietor & 1.038 & 0.181 & 1.038 & 0.196 & 1.132 & 0.195 \\
\hline Laborer & 1.071 & 0.117 & 1.071 & 0.137 & 1.063 & 0.136 \\
\hline \multicolumn{7}{|l|}{ Dummy $=1$ if born in } \\
\hline \multicolumn{7}{|l|}{ US } \\
\hline Germany & 0.922 & 0.159 & 0.922 & 0.164 & 0.918 & 0.164 \\
\hline Ireland & $2.002^{\ddagger}$ & 0.235 & $2.002^{\ddagger}$ & 0.287 & $2.007^{\ddagger}$ & 0.287 \\
\hline Great Britain & $1.686^{\ddagger}$ & 0.273 & $1.686^{\ddagger}$ & 0.279 & $1.691^{\ddagger}$ & 0.280 \\
\hline Other & 1.105 & 0.185 & 1.105 & 0.171 & 1.100 & 0.170 \\
\hline Age at enlistment & $0.985^{\dagger}$ & 0.006 & $0.985^{\dagger}$ & 0.006 & $0.985^{\dagger}$ & 0.006 \\
\hline Height in inches at enlistment & 1.011 & 0.016 & 1.011 & 0.017 & 1.012 & 0.017 \\
\hline Dummy $=1$ if married & 1.142 & 0.207 & 1.142 & 0.218 & 1.141 & 0.218 \\
\hline Log(total household personal property), 1860 & 0.987 & 0.027 & 0.987 & 0.027 & 0.987 & 0.027 \\
\hline Dummy $=1$ if illiterate & 1.087 & 0.361 & 1.087 & 0.315 & 1.076 & 0.314 \\
\hline \multicolumn{7}{|l|}{ Company characteristics } \\
\hline Birth place fragmentation & $2.961^{\ddagger}$ & 0.836 & $2.961^{\ddagger}$ & 1.218 & $3.001^{\ddagger}$ & 1.230 \\
\hline Occupational fragmentation & $2.890^{\ddagger}$ & 1.044 & $2.890^{\dagger}$ & 1.420 & $2.983 \dagger$ & 1.451 \\
\hline Coefficient of variation for age $\times 100$ & 0.994 & 0.015 & 0.994 & 0.025 & 0.993 & 0.025 \\
\hline $\log ($ population) city enlistment & 1.008 & 0.026 & 1.008 & 0.037 & 1.006 & 0.037 \\
\hline \multicolumn{7}{|l|}{ Dummy $=1$ if mustered in } \\
\hline \multicolumn{7}{|l|}{1861} \\
\hline 1862 & $1.303^{\dagger}$ & 0.136 & $1.303^{*}$ & 0.205 & $1.390^{\dagger}$ & 0.216 \\
\hline 1863 & $1.569^{\ddagger}$ & 0.247 & $1.569^{\dagger}$ & 0.285 & $1.748^{\ddagger}$ & 0.322 \\
\hline 1864 & $2.223^{\ddagger}$ & 0.282 & $2.223^{\ddagger}$ & 0.339 & $2.505^{\ddagger}$ & 0.400 \\
\hline 1865 & $1.194^{\ddagger}$ & 0.404 & $1.194^{*}$ & 0.504 & $1.921^{\dagger}$ & 0.503 \\
\hline Dummy $=1$ if volunteer & 0.851 & 0.127 & 0.851 & 0.145 & 0.854 & 0.144 \\
\hline \multicolumn{7}{|l|}{ Percent in county of enlistment voting for } \\
\hline Lincoln & $0.993^{*}$ & 0.004 & 0.993 & 0.004 & 0.994 & 0.004 \\
\hline Percent in company dying (time-varying) & 0.991 & 0.014 & 0.991 & 0.019 & 0.990 & 0.019 \\
\hline Fraction Union victories (time-varying) & & & & & $0.599^{\dagger}$ & 0.128 \\
\hline Duration dependence parameter & 1.226 & 0.041 & 1.226 & 0.051 & 1.325 & 0.072 \\
\hline Clustered on Company & $\mathrm{N}$ & & $\mathrm{Y}$ & & $\mathrm{Y}$ & \\
\hline \multicolumn{7}{|l|}{$\chi^{33}, \chi^{33}, \chi^{34}$ for } \\
\hline Significance all coefficients & 492.83 & & 336.48 & & 349.34 & \\
\hline
\end{tabular}

Days until arrest are measured from first mustering in. The symbols $*, \uparrow$, and $\stackrel{\ddagger}{\dagger}$ indicate that the coefficient is significantly different from 1 at the 10,5, and 1 percent level, respectively. The test for significance of all coefficients is for equality of all coefficients to 1 . Men who died, became POWs, were discharged, were missing in action, changed companies, or deserted before first arrest are treated as censored. Covariates include dummy variables indicating missing information for occupation, the 1860 census, literacy, and county voting. Included region fixed effects are for Middle Atlantic, East North Central, West North Central, Border, and West (New England is the omitted category). 
Table 6: AWOL Competing Risk Hazard Model

\begin{tabular}{|c|c|c|c|c|c|c|}
\hline & $\begin{array}{c}\text { Hazard } \\
\text { Ratio }\end{array}$ & $\begin{array}{l}\text { Std } \\
\text { Err }\end{array}$ & $\begin{array}{c}\text { Hazard } \\
\text { Ratio }\end{array}$ & $\begin{array}{l}\text { Std } \\
\text { Err }\end{array}$ & $\begin{array}{c}\text { Hazard } \\
\text { Ratio }\end{array}$ & $\begin{array}{l}\text { Std } \\
\text { Err }\end{array}$ \\
\hline \multicolumn{7}{|l|}{ Dummy $=1$ if occupation } \\
\hline \multicolumn{7}{|l|}{ Farmer } \\
\hline Artisan & 0.913 & 0.084 & 0.913 & 0.089 & 0.910 & 0.088 \\
\hline Professional/proprietor & 1.049 & 0.135 & 1.049 & 0.146 & 1.045 & 0.146 \\
\hline Laborer & 1.044 & 0.095 & 1.044 & 0.121 & 1.043 & 0.121 \\
\hline \multicolumn{7}{|l|}{ Dummy $=1$ if born in } \\
\hline Germany & 0.862 & 0.116 & 0.862 & 0.144 & 0.857 & 0.143 \\
\hline Ireland & 1.184 & 0.130 & 1.184 & 0.152 & 1.181 & 0.152 \\
\hline Great Britain & 1.245 & 0.184 & 1.245 & 0.219 & 1.247 & 0.219 \\
\hline Other & 0.937 & 0.139 & 0.937 & 0.148 & 0.935 & 0.148 \\
\hline Age at enlistment & 1.003 & 0.005 & 1.003 & 0.005 & 1.004 & 0.005 \\
\hline Height in inches at enlistment & 1.009 & 0.013 & 1.009 & 0.013 & 1.009 & 0.013 \\
\hline Dummy $=1$ if married & 1.212 & 0.145 & 1.212 & 0.148 & 1.211 & 0.147 \\
\hline Log(total household personal property), 1860 & $0.969^{*}$ & 0.018 & 0.969 & 0.021 & 0.968 & 0.021 \\
\hline Dummy $=1$ if illiterate & $1.549^{\dagger}$ & 0.290 & 1.549 & 0.462 & 1.551 & 0.464 \\
\hline \multicolumn{7}{|l|}{ Company characteristics } \\
\hline Birth place fragmentation & $2.580^{\ddagger}$ & 0.535 & $2.580^{\dagger}$ & 1.001 & $2.593^{\ddagger}$ & 1.007 \\
\hline Occupational fragmentation & 0.753 & 0.193 & 0.753 & 0.374 & 0.759 & 0.376 \\
\hline Coefficient of variation for age $\times 100$ & 1.014 & 0.011 & 1.014 & 0.022 & 1.014 & 0.022 \\
\hline $\log$ (population) city enlistment & 1.028 & 0.021 & 1.028 & 0.036 & 1.027 & 0.036 \\
\hline \multicolumn{7}{|l|}{ Dummy $=1$ if mustered in } \\
\hline 1862 & $0.707^{\ddagger}$ & 0.055 & $0.707^{\ddagger}$ & 0.093 & $0.749^{\dagger}$ & 0.099 \\
\hline 1863 & $0.655^{\ddagger}$ & 0.097 & $0.655^{\dagger}$ & 0.135 & 0.729 & 0.154 \\
\hline 1864 & $1.185^{*}$ & 0.117 & 1.185 & 0.200 & 1.326 & 0.232 \\
\hline 1865 & 1.120 & 0.186 & 1.120 & 0.331 & 1.191 & 0.333 \\
\hline Dummy $=1$ if volunteer & $0.649^{\ddagger}$ & 0.075 & $0.649^{\dagger}$ & 0.112 & $0.651^{\dagger}$ & 0.113 \\
\hline \multicolumn{7}{|l|}{ Percent in county of enlistment voting for } \\
\hline Lincoln & $0.990^{\ddagger}$ & 0.002 & $0.990^{\ddagger}$ & 0.003 & $0.990^{\ddagger}$ & 0.003 \\
\hline Percent in company dying (time-varying) & $1.069^{\ddagger}$ & 0.009 & $1.069^{\ddagger}$ & 0.014 & $1.068^{\ddagger}$ & 0.014 \\
\hline Fraction Union victories (time-varying) & & & & & 0.605 & 0.105 \\
\hline Duration dependence parameter & 1.206 & 0.032 & 1.206 & 0.043 & 1.298 & 0.050 \\
\hline Clustered on Company & $\mathrm{N}$ & & $\mathrm{Y}$ & & $\mathrm{Y}$ & \\
\hline $\begin{array}{l}\chi^{33}, \chi^{33}, \chi^{34} \text { for } \\
\text { Significance of all coefficients }\end{array}$ & 405.61 & & 210.85 & & 217.06 & \\
\hline
\end{tabular}

Days until AWOL are measured from first mustering in. The symbols $*, \dagger$, and $\frac{\ddagger}{\grave{\ddagger}}$ indicate that the coefficient is significantly different from 1 at the 10,5, and 1 percent level, respectively. Significance of all coefficients is for equality of all coefficients to 1. Men who died, became POWs, were discharged, were missing in action, changed companies, or deserted before first AWOL are treated as censored. Covariates include dummy variables indicating missing information for occupation, the 1860 census, literacy, and county voting. Included region fixed effects are for Middle Atlantic, East North Central, West North Central, Border, and West (New England is the omitted category). 
Table 7: Promotion to Officer Competing Risk Hazard Model

\begin{tabular}{|c|c|c|c|c|c|c|c|c|}
\hline & $\begin{array}{c}\text { Hazard } \\
\text { Ratio }\end{array}$ & $\begin{array}{l}\text { Std } \\
\text { Err }\end{array}$ & $\begin{array}{c}\text { Hazard } \\
\text { Ratio }\end{array}$ & $\begin{array}{l}\text { Std } \\
\text { Err }\end{array}$ & $\begin{array}{c}\text { Hazard } \\
\text { Ratio }\end{array}$ & $\begin{array}{l}\text { Std } \\
\text { Err }\end{array}$ & $\begin{array}{c}\text { Hazard } \\
\text { Ratio }\end{array}$ & $\begin{array}{l}\text { Std } \\
\text { Err }\end{array}$ \\
\hline \multicolumn{9}{|l|}{ Dummy $=1$ if occupation } \\
\hline \multicolumn{9}{|l|}{ Farmer } \\
\hline Artisan & $1.321^{*}$ & 0.214 & $1.321^{*}$ & 0.214 & $1.338^{*}$ & 0.216 & $1.332^{*}$ & 0.214 \\
\hline Professional/proprietor & $2.480^{\ddagger}$ & 0.470 & $2.480^{\ddagger}$ & 0.517 & $2.541^{\ddagger}$ & 0.531 & $2.491^{\ddagger}$ & 0.516 \\
\hline Laborer & 0.983 & 0.202 & 0.983 & 0.190 & 0.999 & 0.194 & 0.974 & 0.181 \\
\hline \multicolumn{9}{|l|}{ Dummy $=1$ if born in } \\
\hline \multicolumn{9}{|l|}{ US } \\
\hline Germany & 0.770 & 0.202 & 0.770 & 0.219 & 0.785 & 0.224 & $0.569^{\dagger}$ & 0.166 \\
\hline Ireland & 0.607 & 0.189 & 0.607 & 0.209 & 0.607 & 0.209 & $0.566^{*}$ & 0.194 \\
\hline Great Britain & 0.920 & 0.290 & 0.920 & 0.311 & 0.918 & 0.310 & 0.792 & 0.280 \\
\hline Other & 0.713 & 0.212 & 0.713 & 0.245 & 0.705 & 0.241 & 0.601 & 0.203 \\
\hline Age at enlistment & 0.999 & 0.009 & 0.999 & 0.010 & 0.998 & 0.010 & 0.998 & 0.010 \\
\hline Height in inches at enlistment & $1.115^{\ddagger}$ & 0.024 & $1.115^{\ddagger}$ & 0.025 & $1.116^{\ddagger}$ & 0.025 & $1.117^{\ddagger}$ & 0.025 \\
\hline Dummy $=1$ if married & 1.063 & 0.218 & 1.063 & 0.243 & 1.063 & 0.244 & 1.027 & 0.243 \\
\hline Log(total household personal property), 1860 & 1.013 & 0.032 & 1.013 & 0.047 & 1.014 & 0.047 & 0.994 & 0.048 \\
\hline Dummy $=1$ if illiterate & $0.192^{*}$ & 0.193 & 0.192 & 0.196 & 0.189 & 0.194 & 0.196 & 0.200 \\
\hline \multicolumn{9}{|l|}{ Company-level measures } \\
\hline Birth place fragmentation & $3.102^{\ddagger}$ & 1.222 & 3.102 & 3.131 & 2.267 & 2.256 & 1.027 & 0.628 \\
\hline Occupational fragmentation & $0.249^{\ddagger}$ & 0.110 & $0.249^{\dagger}$ & 0.177 & $0.256^{*}$ & 0.183 & 0.279 & 0.222 \\
\hline Coefficient of variation for age $\times 100$ & $0.972^{*}$ & 0.016 & 0.972 & 0.037 & 0.969 & 0.037 & 0.969 & 0.037 \\
\hline Log(population) city enlistment & 1.036 & 0.046 & 1.036 & 0.078 & 1.035 & 0.077 & 1.095 & 0.078 \\
\hline \multicolumn{9}{|l|}{ Dummy $=1$ if mustered in } \\
\hline \multicolumn{9}{|l|}{1861} \\
\hline 1862 & $0.687^{\ddagger}$ & 0.098 & 0.687 & 0.160 & $0.647^{*}$ & 0.148 & $0.591^{\dagger}$ & 0.144 \\
\hline 1863 & $0.574^{*}$ & 0.171 & 0.574 & 0.266 & 0.507 & 0.231 & $0.467^{*}$ & 0.193 \\
\hline 1864 & $0.478^{\ddagger}$ & 0.100 & $0.478^{*}$ & 0.205 & $0.425^{\dagger}$ & 0.187 & $0.366^{\ddagger}$ & 0.149 \\
\hline 1865 & $2.319^{\ddagger}$ & 0.429 & $2.319^{\ddagger}$ & 0.796 & $2.552^{\ddagger}$ & 0.884 & $1.193^{\dagger}$ & 0.668 \\
\hline \multicolumn{9}{|l|}{ Percent in county of enlistment voting for } \\
\hline Lincoln & 1.004 & 0.005 & 1.004 & 0.008 & 1.003 & 0.007 & 0.997 & 0.007 \\
\hline Percent in company dying (time-varying) & 1.001 & 0.013 & 1.001 & 0.021 & 1.012 & 0.020 & 1.017 & 0.020 \\
\hline Fraction Union victories (time-varying) & & & & & $2.799^{\ddagger}$ & 0.740 & $2.795^{\ddagger}$ & 0.705 \\
\hline Duration dependence parameter & 0.657 & 0.033 & 0.657 & 0.062 & 0.575 & 0.055 & 0.569 & 0.053 \\
\hline Clustered on Company & $\mathrm{N}$ & & $\mathrm{Y}$ & & $\mathrm{Y}$ & & $\mathrm{Y}$ & \\
\hline Dummies for Iowa and Wisconsin & $\mathrm{N}$ & & $\mathrm{N}$ & & $\mathrm{N}$ & & $\mathrm{Y}$ & \\
\hline \multicolumn{9}{|l|}{$\chi^{32}, \chi^{32}, \chi^{33}, \chi^{35}$ for } \\
\hline Significance of all coefficients & 334.09 & & 264.24 & & 284.61 & & 336.39 & \\
\hline
\end{tabular}

Days until promotion are measured from first mustering in. The symbols $*, \dagger$, and $\ddagger$ indicate that the coefficient is significantly different from 1 at the 10,5, and 1 percent level, respectively. The significance of all coefficients is for equality of all coefficients to 1. Men who died, became POWs, were discharged, were missing in action, changed companies, or deserted before first promotion to officer are treated as censored. Covariates include dummy variables indicating missing information for occupation, the 1860 census, literacy, and county voting. Included region fixed effects are for Middle Atlantic, East North Central, West North Central, Border, and West (New England is the omitted category). 
men. Married men were more likely to be AWOL (but not significantly so), probably because furloughs were generally granted only to married men thus providing them with an opportunity to go AWOL. The most important individual characteristics predicting promotion to officer were social status, birth place, and height. Professionals or proprietors and artisans were more likely to be promoted than farmers or laborers. Men born abroad were less likely to be promoted than the native-born and the tall were more likely to be promoted. Whether a soldier was owed a bounty (as was true for many volunteers after 1862), decreased desertion rates (not shown), but the effect was not statistically significant. ${ }^{13}$

Community characteristics were also important predictors of cowardice and of heroism. Men who came from companies in which birth place, occupation, and age heterogeneity was high were all more likely desert. Although birth place fragmentation was not a statistically significant predictor of desertion when we clustered on companies, it became a statistically significant predictor when we dropped occupational fragmentation from the regression. Men in companies in which birth place and occupational diversity was high were significantly more likely to be arrested. The only company socioeconomic and demographic characteristic that significantly predicted AWOL was birth place diversity. Note that although high birth place diversity is a positive, but insignificant predictor of promotion once we cluster on companies, it becomes a negative predictor of promotion once we add dummies for Iowa and Wisconsin, the two states with unusually high promotion rates. When we included the company Gini coefficient for both personal and property wealth calculated from the 1860 census, we found that while men in companies where inequality was high were more likely to desert, the effect was statistically insignificant. Men who enlisted in large cities were more likely to desert (perhaps because they

\footnotetext{
${ }^{13}$ God was not necessarily a better motivator than mammon. The higher the ratio of church seats to county of enlistment population, the higher the desertion rate. However, this ratio is probably a proxy for urbanization. We could find no clear pattern by type of religion.
} 
faced fewer community sanctions and because they were less likely to know the men in their company).

We have a unique opportunity to study peer groups for brothers, fathers, and sons among men linked to the 1860 census. These men might either be more likely to shirk because collusion is easier or be less likely to shirk because of loyalty. We find that having close kin in the same company increased the probability of desertion, but the coefficient was not statistically significant. It decreased significantly decreased the odds of going AWOL and did not affect arrests.

As previously noted, we have not attempted to identify endogeneous interactions. However, because of the non-linearity of our estimation equation, the endogeneous interaction can be estimated off of the functional form (Manksi 1993, 2000; Brock and Durlauf 2001). We therefore included a time-varying measure of the fraction in the company deserting in our desertion specification as a robustness check. We found that this measure significantly increased desertion rates, but that the company death rate became an insignificant predictor of desertion and that the significance of the coefficient on the proportion of Union victories fell from 1 to 10 percent. All other coefficients were unaffected.

We find no evidence of a true "dark" side of social capital, but we do find some evidence of ethnic favoritism. We did not find that company characteristics predicted battlefield mortality among men, suggesting that more homogeneous companies were not successful in colluding to straggle away from the front lines. We investigated whether there was any interaction between own ethnicity and that of a company officer for the limited set of companies for which we know something about the officers because they rose from the ranks. In the case of AWOL, the Irish were significantly more likely to be AWOL if the company had an Irish officer, but we could not determine if punishments for AWOL were lower in these companies. However, both the Irish and the British were more likely to be arrested if the company contained an Irish or British officer and the British were significantly less likely to desert if the contained a British officer. We also 
investigated whether the interactions between own occupation and the proportion of men in the company in that occupation and own birth place and the proportion of men of that ethnicity were at all significant. The Irish were less likely to be arrested if the proportion of Irish in the company was high. Soldiers were more likely to desert if the at least 50 percent of the company was Irish, but the Irish were significantly less likely to desert if at least 50 percent of the company was Irish. Artisans were less likely to desert or to be arrested if the proportion of artisans in the company was high. However, laborers were more likely to desert and to be arrested if the proportion of laborers in the company was high.

Ideology predicted desertion, arrest, and AWOL, but not promotion to officer. Men who enlisted in 1861 were less likely to desert or to be arrested. Surprisingly, soldiers mustered in 1862 and 1863 were less likely to be AWOL than soldiers mustered in 1861 and men mustered in 1865 were more likely to be promoted than men mustered in 1861 . However, men mustered in 1861 were more likely to be promoted than men mustered in 1862-1864. Men who volunteered and men from pro-Lincoln counties were less likely to desert or to be AWOL. We find mixed evidence that soldiers became more committed to the cause the longer they remained in the army. Although desertion hazards decrease with time, arrest and AWOL hazards increase with time and promotion hazards decrease with time.

Lastly, morale was a predictor of all of our measures of cowardice and of heroism. Men were more likely to desert when company mortality was high and when the Union was losing. Arrest rates were higher when the Union was losing. A high company mortality rate significantly reduced time until AWOL. When the Union was winning time until promotion to officer was shorter perhaps because enlisted men exerted extra effort and therefore were more likely to be promoted.

We experimented with different outcome variables. We investigated what predicted re-enlistment for another 3 year term among men who enlisted in 1861 and who had already 
served a 3 year term. Approximately half of re-enlistees in the sample received a bounty upon re-enlistment. Generally men re-enlisted as regiments or companies (Hess 1997: 89). Older men, men from large cities, and Germans were less likely to re-enlist and men who received a bounty for re-enlisting were more likely to re-enlist, but these were the only characteristics that predicted re-enlistment. ${ }^{14}$ We also combined desertion, arrest, and AWOL as one outcome measure of “cowardice," finding that birth place and occupational fragmentation, age diversity, enlisting in a large city, enlisting at a late date, a small pro-Lincoln vote, a high company death rate, a low fraction of Union victories, and being a non-farmer, Irish, or British rather than native-born, younger, poorer, and illiterate all led to higher cowardice rates.

We performed further robustness tests by experimenting with state fixed effects for all regressions. When we combined desertion, arrest, and AWOL as one outcome measure of "cowardice," we found that difficulties we faced is that when the number of companies within a state was small correlation between birth place and occupational fragmentation was high. In the case of promotion to officer, AWOL, and arrest, the coefficients on company socioeconomic and demographic characteristics, the percentage of the county voting for Lincoln, and the company death rate remained unchanged. For desertion, both birth place and occupational fragmentation were statistically significant predictors of desertion, but the proportion of the county voting for Lincoln (a measure that varies more across states than within states) became an insignificant predictor.

\footnotetext{
${ }^{14}$ There was no dishonor in not re-enlisting. Newton Scott, a private in the 36th Iowa Infantry, Company A, wrote to Hannah Cone, "I think it the Duty of Every Able Bodied man If Necessary to Help Defend His country But I think 3 years Sufficient long for one man to Serve while they all take there [sic] turns..." http://www.civilwarletters.com
} 
Table 8: Predicted Probabilities of Desertion, Arrest, AWOL, and Promotion to Officer By Company Characteristics, Morale, and Ideology

\begin{tabular}{lllll}
\hline \hline & Desertion & Arrest & AWOL & Promotion \\
\hline Using true variable values & 0.094 & 0.020 & 0.033 & 0.011 \\
Community characteristics & & & & \\
$\quad$ If birthplace fragmentation=0 & 0.078 & 0.010 & 0.019 & 0.010 \\
$\quad$ If occupational fragmentation=0 & 0.047 & 0.010 & 0.039 & 0.019 \\
$\quad$ If coefficient of variation for age=0 & 0.042 & 0.023 & 0.023 & 0.025 \\
$\quad$ If all of above & 0.016 & 0.006 & 0.016 & 0.043 \\
If population in city of enlistment=2500 & 0.088 & 0.020 & 0.032 & 0.011 \\
If all of above & 0.015 & 0.006 & 0.015 & 0.042 \\
Morale & & & & \\
If company death rate=0 & 0.084 & 0.020 & 0.027 & 0.010 \\
If fraction Union victories=1 & 0.067 & 0.015 & 0.034 & 0.021 \\
If both & 0.060 & 0.022 & 0.028 & 0.020 \\
Ideology & & & & \\
If volunteer & 0.091 & 0.020 & 0.032 & \\
If 86.6\% county voted for Lincoln & 0.079 & 0.015 & 0.022 & 0.009 \\
If mustered in 1861 & 0.066 & 0.015 & 0.039 & 0.015 \\
If all of above & 0.054 & 0.011 & 0.025 & 0.013 \\
\hline \hline
\end{tabular}

Desertion, AWOL, and arrest probabilities are predicted from the third specifications in Tables 4, 5, and 6, respectively. Promotion to officer is predicted from the fourth specification in Table 7. In this sample, the largest share of the vote Lincoln received in a county was $86.6 \%$. Cities with a population of less than 2500 were not even listed in the census and are therefore considered small towns.

\section{Implications for Organizational Design}

What do our results imply about designing a well functioning military organization? Table 8 shows the relative importance of community socioeconomic and demographic characteristics, morale, and ideology for the predicted probability of desertion, arrest, AWOL, and promotion to officer. (This table also provides a good indication of the magnitude of the coefficients on our variables.) In the case of desertion the single most important variables were age and occupational diversity within the company. In the case of arrests, birth place and occupational fragmentation, 
the fraction of Union victories, the percentage of the county voting for Lincoln, and year of muster were the single most important predictors. Birth place diversity, age diversity and the fraction of the county voting for Lincoln were the most important predictors of AWOL. The single most important predictors of promotion to officer were age diversity and the fraction of Union victories. On the whole company socioeconomic and demographic characteristics were the most important predictors of desertion, arrest, AWOL, and promotion to officer. Morale was relatively more important than ideology for promotion to officer and ideology was relatively more important than morale for desertion, arrest, and AWOL.

Why does the Army today not make greater use of social capital by creating socioeconomic and demographically homogeneous fighting units? Two reasons include diversification and human capital specialization in the modern army. Drawing companies on the local level ended after highly-publicized losses to communities during World War II. In the modern army, soldiers perform a myriad of tasks requiring different training. Because their skills are not perfect substitutes, the modern army is more likely to face a bundling problem which inhibits it from achieving the high level of social capital that the "old" army could achieve.

\section{Conclusion}

What motivates loyalty to an organization? Is it the attributes of a person, the socio-economic and demographic characteristics of the organization, the attributes of the organization's leader, belief in the organization's mission, or self-interest? Recent studies have argued that sacrifice among Ultra-Orthodox Jews provides them with self-insurance benefits (Berman 2000) and that loyalty to street gangs can provide future riches (Levitt and Venkatesh 2000). Iannaccone (1992) argues that efficient religions may benefit from self-sacrifice because of free rider problems. In contrast, loyal Union Army soldiers gained little monetary compensation, only the knowledge that they 
could hold their heads high among their comrades and in their home towns (McPherson 1997: 77-84). In such an organization creating group loyalty is of paramount importance. Group loyalty in the Civil War was the "cement of the armies," allowing both the Union and the Confederacy to mount comprehensive military efforts even though indiscipline was chronic, military training scant, and the system of military justice weak (Linderman 1987: 35-36).

How was this group loyalty created? Individual socio-economic and demographic characteristics, company socio-economic and demographic characteristics, ideological committment, and morale were all important determinants of group loyalty among Union Army soldiers in the Civil War. Company socio-economic and demographic characteristics were particulary important, even more so than ideological committment and morale. However, while homogeneous companies were more successful in accomplishing the short-run goal of fielding full companies, we cannot ascertain whether there were any long-run benefits of being in a heterogenous company to individual soldiers.

\section{Data Appendix}

This appendix describes the construction of our demographic and socio-economic variables, our community variables, our ideology variables, and our morale variables. All data on Union Army recruits are obtained from Aging of Veterans of the Union Army, Robert W. Fogel, Principal Investigator, http://www.cpe.uchicago.edu.

\section{Socio-economic and Demographic Characteristics}

1. Dependent variable. We calculated days from muster until desertion, arrest, AWOL, or promotion to officer. We allowed for censoring by also calculating days from muster until death, discharge, changing company, becoming prisoner of war, or missing in action.

2. Occupation. Dummy variables indicating whether at enlistment the recruit reported his occupation as farmer, artisan, professional or proprietor, or laborer. Farmers' sons who 
were not yet farmers in their own right would generally report themselves as farmers.

3. Birth place Dummy variables indicating whether at enlistment the recruit reported his birth place as the US, Germany, Ireland, Great Britain, or other.

4. Age at enlistment. Age at first enlistment.

5. Height in inches. Height in inches at first enlistment.

6. Married in 1860. This variable is inferred from family member order and age in the 1860 census. This variable was set equal to 0 if the recruit was not linked to the 1860 census.

7. Log(total household personal property) in 1860. This variable is the sum of personal property wealth of everyone in the recruits' 1860 household. This variable is set equal to 0 is the recruit was not linked to the 1860 census.

8. Missing census information. A dummy equal to one if the recruit was not linked to the 1860 census. Linkage rates from the military service records to the 1860 census were 57 percent. The main characteristic that predicted linkage failure was foreign birth.

9. Illiterate. This variable is from the 1860 census and provides illiteracy information only for those age 20 and older.

10. Missing illiteracy information. A dummy equal to one if we do not know whether the recruits was illiterate, either because he was not linked to the 1860 census or because he was less than age 20 in 1860.

11. Region effects. Our region dummies are New England, Middle Atlantic, East North Central, West North Central, Border, and West.

\section{Community Characteristics}

1. Birth place fragmentation. We calculated, by company, the fraction of individuals born in the US in New England, in the Middle Atlantic, in the East North Central, in the West North Central, the Border states, the south, and the west and born abroad in Germany, Ireland, Canada, Great Britain, Scandinavia, northwestern Europe (France, Belgium, Luxembourg, the Netherlands), other areas of Europe, and other areas of the world. Our birthplace fragmentation index, $f_{i}$, is then

$$
f_{i}=1-\sum_{k} s_{k i}^{2}
$$

where $k$ represents the categories and where $s_{k i}$ is the share of men of born in place $k$ in company $i$. 
2. Occupational fragmentation. We calculated, by company, the fraction of individuals who were farmers, higher class professionals and proprietors, lower class professionals and proprietors, artisans, higher class laborers, lower class laborers, and unknown. Our occupational fragmentation index is then calculated similarly to our birthplace fragmentation index.

3. Coefficient of variation for age. We calculated, by company, the coefficient of variation for age at enlistment.

4. Population in city of enlistment. We obtained population in city of enlistment from Union Army Recruits in White Regiments in the United States, 1861-1865 (ICPSR 9425), Robert W. Fogel, Stanley L. Engerman, Clayne Pope, and Larry Wimmer, Principal Investigators. Cities that could not be identified were assumed to be cities of population less than 2,500.

\section{Ideology Variables}

1. Year of muster. Dummy variables indicating the year that the soldier was first mustered in.

2. Volunteer. A dummy equal to one if the recruit was a volunteer instead of a draftee or a substitute.

3. Percent of vote in $\mathbf{1 8 6 0}$ Presidential election. We obtained by county of enlistment the fraction of the vote case for Lincoln and for other candidates from Electoral Data for Counties in the United States: Presidential and Congressional Races, 1840-1972 (ICPSR 8611), Jerome M. Clubb, William H. Flanigan, and Nancy H. Zingale, Principal Investigators. Because we cannot attribute a county to each recruit, our categories are percent in county of enlistment voting for Lincoln, other candidate, and unknown.

\section{Morale Variables}

1. Fraction in company dying. We calculated, by company, the fraction dying overall and the fraction dying (among all men at risk to die) within all half years that each recruit served. Our means present the fraction dying overall. Our regression results use the time-varying covariate, fraction of men at risk dying during all half years that each recruit served.

2. Fraction of major Union victories. This is a time-varying variable that indicates for each half year that the recruit was in the service the fraction of major Union victories to all major battles in that half-year. It takes the value 0 if there were no major battles. 


\section{References}

[1] Alesina, Alberto, Reza Baqir, and William Easterly. 1999. "Public Goods and Ethnic Divisions." Quarterly Journal of Economics. 114(4): 1243-1284.

[2] Alesina, Alberto and Eliana La Ferrara. 2000. "Participation in Heterogeneous Communities." Quarterly Journal of Economics. 115(3): 847-904.

[3] Bearman, Peter S. 1991. "Desertion as Localism: Army Unit Solidarity and Group Norms in the U.S. Civil War." Social Forces. 70(2): 321-342.

[4] Berman, Eli. 2000. "Sect, Subsidy, and Sacrifice: An Economist's View of Ultra-Orthodox Jews.” Quarterly Journal of Economics. 115(3): 905-954.

[5] Brock, William A. and Steven N. Durlauf. 2001. "Discrete Choice with Social Interactions." Review of Economic Studies. 68(2): 235-60.

[6] Cai, T, L.J. Wei, and M. Wilcox. 2000. "Semiparametric Regression Analysis for Clustered Failure Time Data.” Biometrika. 87(4): 867-878.

[7] Coleman, James. 1990. Foundations of Social Theory. Cambridge, MA: Harvard University Press.

[8] Costa, Dora L. and Matthew E. Kahn. "Understanding the Decline in Social Capital, 19521998.” National Bureau of Economic Research Working Paper 8295.

[9] Dollard, John. 1943. Fear in Battle. New Haven, CT: The Institute of Human Relations, Yale University.

[10] Fogel, Robert W. 1989. Without Consent or Contract: The Rise and Fall of American Slavery. New York: W.W. Norton and Company.

[11] Fogel, Robert W. 2001. "Early Indicators of Later Work Levels, Disease, and Death.” Grant submitted to NIH, February 1, 2001.

[12] Gibbons, Robert. "Incentives in Organizations.” Journal of Economic Perspectives. 12(4): 115-132.

[13] Glaeser, Edward L., David Laibson, and Bruce Sacerdote. 2000. “The Economic Approach to Social Capital.” National Bureau of Economic Research Working Paper 7728.

[14] Glaeser, Edward L., David I. Laibson, José A. Scheinkman, and Christine L. Soutter. 2000. “Measuring Trust." Quarterly Journal of Economics. 115(3): 715-1090.

[15] Goldin, Claudia and Lawrence F. Katz. 1999. "Human Capital and Social Capital: The Rise of Secondary Schooling in America, 1910 to 1940." Journal of Interdisciplinary History. 29: 683-723. 
[16] Gould, Benjamin Apthrop. 1869. Investigations in the Military and Anthropological Statistics of American Soldiers. New York: Published for the United States Sanitary Commission by Hurd and Houghton.

[17] Guiso, Luigi, Paola Sapienza, and Luigi Zingales. 2000. "The Role of Social Capital in Financial Development.” National Bureau of Economic Research Working Paper 7563.

[18] Hattaway, Herman M. 1997. "The Civil War Armies: Creation, Mobilization, and Development." In Stig Föster and Jörg Nagler, Editors, On the Road to Total War: The American Civil War and the German Wars of Unification, 1861-1871. Cambridge-New York: German Historical Institute and Cambridge University Press: 173-198.

[19] Hess, Earl J. 1997. The Union Soldier in Battle: Enduring the Ordeal of Combat. Lawrence, KS: University Press of Kansas.

[20] Holmström, Bengt. 1982. "Moral Hazard in Teams." Bell Journal of Economics. 13(2): 324-40.

[21] Iannaccone, Laurence R. 1992. "Sacrifice and Stigma: Reducing Free-Riding in Cults, Communes, and Other Collectives.” Journal of Political Economy. 100(2): 271-291.

[22] Ichino, Andrea and Giovanni Maggi. 2000. "Work Environment and Individual Background: Explaining Regional Shirking Differentials in a Large Italian Firm.” Quarterly Journal of Economics. 115(3): 1057-1090.

[23] Kemp, Thomas R. 1990. "Community and War: The Civil War Experience of Two New Hampshire Towns.” In Maris A. Vinovskis, Editor, Toward a Social History of the American Civil War: Exploratory Essays. New York-Cambridge: Cambridge University Press: 1-30.

[24] Knack, Stephen and Philip Keefer. 1997. "Does Social Capital Have an Economic Payoff? A Cross-Country Investigation.” Quarterly Journal of Economics. 112(4): 1251-1288.

[25] La Porta, Rafael, Florencio Lopez-de-Silanes, Andrei Schleifer, and Robert W. Vishny. 1997. “Trust in Large Organizations.” American Economic Review. 87(2): 333-338.

[26] Lazear, Edward P. 1979. "Why is There Mandatory Retirement?" Journal of Political Economy. 87(6): 1261-84.

[27] Lee, W.W, L.J. Wei, and D.A. Amato. 1992. "Cox-type Regression Analysis for Large Numbers of Small Groups of Correlated Failure Time Observations.” In J.P. Klein and P.K. Goel, Editors, Survival Analysis: State of the Art. Dordrecht: Kluwer: 237-247.

[28] Levitt, Steven D. and Sudhir Alladi Venkatesh. 2000. "An Economic Analysis of a DrugSelling Gang's Finances.” Quarterly Journal of Economics. 115(3): 755-790.

[29] Linderman, Gerald F. 1987. Embattled Courage: The Experience of Combat in the American Civil War. New York: The Free Press. 
[30] Luttmer, Erzo F.P. 2001. "Group Loyalty and the Taste for Redistribution." Journal of Political Economy. 109(3): 500-528.

[31] Marshall, Samuel L.A. 1947. Men Against Fire: The Problem of Battle Command in Future War. New York: Morrow.

[32] Manski, Charles F. 1992. "Identification of Endogenous Social Effects: The Reflection Problem.” Review of Economic Studies. 60(3): 531-542.

[33] Manski, Charles F. 2000. "Economic Analysis of Social Interactions." Journal of Economic Perspectives. 14(3): 115-136.

[34] McPherson, James M. 1997. For Cause and Comrades: Why Men Fought in the Civil War. Oxford-New York: Oxford University Press.

[35] Mitchell, Reid. 1990. "The Northern Soldier and His Community.” In Maris A. Vinovskis, Editor, Toward a Social History of the American Civil War: Exploratory Essays. New York-Cambridge: Cambridge University Press: 1-30.

[36] O'Reilly, C.A., D.F. Caldwell, and W.P. Barnett. 1989. "Work Group Demography, Social Integration, and Turnover." Administrative Science Quarterly. 34: 21-37.

[37] Pfeffer, Jeffrey. 1997. New Directions for Organization Theory. New York-Oxford: Oxford University Press.

[38] Poterba, James M. 1997. "Demographic Structure and the Political Economy of Public Education." Journal of Policy Analysis and Management. 16(1): 48-66.

[39] Sørenson, Jesper B. 2000. "The Longitudinal Effects of Group Tenure Composition on Turnover." American Sociological Review. 65: 298-310.

[40] Stouffer, Samuel, A. et al. 1949. The American Soldier: Combat and its Aftermath, Volume II. Princeton, NJ: Princeton University Press.

[41] United States Provost Marshall General. 1866. Final Report. United States House of Representatives, Executive Document No. 1, 39th Congress, 1st Session, Series Numbers 1251, 1252.

[42] Vinovskis, Maris A. 1990. "Have Social Historians Lost the Civil War? Some Preliminary Demographic Speculations." In Maris A. Vinovskis, Editor, Toward a Social History of the American Civil War: Exploratory Essays. New York-Cambridge: Cambridge University Press: $1-30$.

[43] Watson, Peter. 1978. War on the Mind: The Military Uses and Abuses of Psychology. New York: Basic Books. 